\title{
STUDENTS' CONFLICT IN SCHOOLS
}

\author{
Tara Bahadur Thapa
}

Department of EPM. TU, Thakur Ram Multiple Campus, Birganj, Nepal

email: thapasirı@gmail.com

\begin{abstract}
This paper is focused on students' conflict in schools and its main propose is
to explore the causes and effects of students' conflict in school level. The result
revealed that the majority of the students' are included by any types of the
conflicts. Reasons for such conflict were: interest of opposite sex, aggressive
behavior, teaching learning process and other activities like difference in
individual capabilities, difference in their socio-economic backgrounds at home.
It was also noted that bulling factors also cause of conflicts and girls are more
victimized. The study would help students, teachers, school administrators and
academicians as well as policy makers.
\end{abstract}
\section{Keywords}

Conflict; violence; bulling; victim; resolution

\section{Introduction}

People all over the world have different perspectives on life and their problems, depending upon the environment in which they live. In the society, conflicts found everywhere. Each conflict has a reason behind it. Derosier (2005) viewed that conflict usually occurs when two or more individuals or groups feel they have contradictory differences. Further he said that conflict is struggle between two or more people over values and competition for status, power and scarcity of resources. In that sense, conflict can arise however close friends, family members, coworkers, or idealistic partner disagree about their perceptions, desires or values.
Conflict is when two or more values, perspectives and opinions are contradictory in nature and have not been values and perspectives are threatened; or discomfort from fear of the unknown or from lack of fulfillment (Upreti, 2005). The conflicts arisen due to the discriminations in a family, racial and sexual, unequal distribution of power and resources, and also disagreement in the society due to the religious, socio- economic and other reasons. Similarly, in the school which is the essential part of society, different religions, cultures, traditions, trends, political values, economic values develop together representing the different societies (Adomi, \& Anie, 2005). As a result the conflict arises among the students of the school having 
different norms and values, desires and selfishness.

Similarly, in the schools, students deviate from their studies and even leave the school or dropout their classes due to the contradictions arisen in their mutual thoughts, norms and values. Sometime in the schools, there is a problem of suffering between boys and girls when two or more boys get attracted to a girl. Therefore, it is essential to diagnose the root causes of the problem and solve it.

Academicians equally agree that most schools now spend little time on academics because discipline consumes so much time, which has negative impacts on the academic standards and performance. It is also widely acknowledged that violence against teachers, other students, and destruction of property both in the learning institution and surrounding communities has really increased in the past years (Thapa, 2010). A school environment has diverse values, beliefs and attitudes making it inevitable for conflicts to occur among students, parents, teachers and staff.

Children attain different knowledge and skills in school. Students can develop their cognition, social behavior, self- confidence, and moral characters in the school. These are the aims of education, however; it is a difficult task to define the aims of schooling. Education as such has no aims but only the teachers, parents, and the persons have aims. Because all of them enter the school in order to fulfill their individual interests and desires. Interestingly, they have dissimilar interests (Pollard, 1994).

Education is the light of knowledge and school is the miniature of society. Education may vary indefinitely according to their differing nature. It is true that the different ways in which children learn, and their different attitudes in learning lie at the heart of any education system However, the problem is how to address the individual child's learning requirements. These situations create educational debate, contradiction, and even consequent conflict in the school.

Likert (1976) said that there are many factors which have actively been creating the situation of conflict in school, such as interpersonal differences, difference in feelings, norms and values, and interest, gender inequality, not being used the appropriate teaching materials and methodologies by teachers. Administrative weakness, lack practices of reward and punishment system, poor communication among staff, stakeholders, economic differences and various political interferences. It not beyond the solution, but there should be proper understanding and effective communication.

There are so many ways to manage the conflict occurs in school. But the responsibility to manage the conflict should be given to head teacher teachers only because he knows all the aspect very clearly. In fact communication has its great role in conflict management in school, so the head teacher, teacher and the member of school management committee should be given the training (Upadhyay, 2010).

Fisher (1997) maintains that since school is an entity which composes of different people with different generational ages and that negotiation and mediation must be identified as the best strategies for eliminating conflict. Three types of situation demand from the negotiation to face to face and find solution to them, these situations are task and relationship oriented conflict and compromise and win conflict. The focus of this study is to understand the causes of conflicts and their implications in teaching learning from the students' perspectives.

\section{Methods}

This article is based on mixed research design. Random sampling method used to select eight public schools in Birgunj City. A sample of school was selected and head teacher, class teacher each school purposively. Hence, in this 
study 80 students with girls and 16 guardians (25\% of students) were randomly selected to participate. Questionnaire, interview, focus group discussion and observation were the tools used to collect information. The information collected was coded, tabulated and percentages were worked out in readiness for analysis. Information gathered from questionnaire was tallied and convert to percentages and analysis accordingly. Document analysis and observation was also used to crosscheck the information from interview schedules. The study delimited to the school level and focus only to students' perspective.

\section{Results and discussion}

In this section data has been analyze and result has been presented under the head: causes, effects and suggestive measure of conflict management.

\section{Causes of students' conflicts in schools}

The five top most causes of conflicts are: interest of opposite sex, aggressive behavior, feeling of superiority of classes, teaching learning activities and others. The more details causes of conflict have been given Table 1 .

Table 1 : Causes of students' conflicts in schools

\begin{tabular}{|c|c|c|c|}
\hline S.N. & Causes & Number & Percent \\
\hline 1 & $\begin{array}{l}\text { Interest of } \\
\text { opposite sex }\end{array}$ & 28 & 35 \\
\hline 2 & $\begin{array}{l}\text { Aggressive } \\
\text { behavior }\end{array}$ & 18 & 22.50 \\
\hline 3 & $\begin{array}{l}\text { Feeling of } \\
\text { superiority of } \\
\text { classes }\end{array}$ & 12 & 15 \\
\hline 4 & $\begin{array}{l}\text { Teaching } \\
\text { learning } \\
\text { activities }\end{array}$ & 11 & 13.75 \\
\hline 5 & Others & 11 & 13.75 \\
\hline 6 & Grand total & 80 & 100 \\
\hline
\end{tabular}

Table 1 indicates that 35 percent students get involved in conflict aggressive behavior. The findings point out that rarely do conflicts arias among due to their teaching learning process. Only 13.75 percent of them involved conflict due to teaching learning activities. It clarifies that students are engaged more in out of teaching learning activities rather than academic activities. Others conflict arises due to different in individual capabilities, different in their socio-economic backgrounds back at home and limited facilities etc.

\section{Effect of students' conflicts in schools}

Communication of students: According to mention the students on questionnaire 57 students do not have communicated or disturbance relation with each other due to different causes. Only 23 students have open relationship with each other. It reveals that the majority of the students are included by any of the conflict. The causes of disturbances open relation of students has been given in Table 1

Table 2: Disturbance of communication

\begin{tabular}{|l|l|c|c|}
\hline S.N. & Causes & Number & Percent \\
\hline 1 & $\begin{array}{l}\text { Violence of each } \\
\text { others }\end{array}$ & 27 & 33.75 \\
\hline 2 & $\begin{array}{l}\text { Violence of his / } \\
\text { her parents }\end{array}$ & 12 & 15 \\
\hline 3 & $\begin{array}{l}\text { Victim of } \\
\text { conflict }\end{array}$ & 18 & 22.50 \\
\hline 4 & Clash of feeling & 23 & 28.75 \\
\hline 5 & Grand total & 80 & 100 \\
\hline \multicolumn{4}{|c|}{ Source: field survey, 2013 }
\end{tabular}

Table 2 shows that most of the students (33.75\%) do not speak with each other due to the violence with each other and 28.75 percent of them due to the clash of feeling. The study has also shown that students do not have open relationships or disturbance relation with each other and conflict takes the form of constant non-calling and radically by boys a year senior. 
One of the research participants (girl student) tried to shed light on her predicament: "They teach me about the way I walk. After the assembly, they pass loud comments. I don't know why they target me. It feels really bad thinking so I was beat. I never conversed with them openly".

Dropout of students due to conflict: Although research participants indicate that a student who has low educational and occupational aspiration, misbehavior in school and pregnancy are related to the individual causes of dropout. Additionally, socioeconomic status of students or his/her parents, students living single parents home and with stepfamilies are related to contextual causes of dropout, findings indicate that main cause of dropout is related to variety of conflict. Study indicates that bulled nature of students and being a victim of conflict both factors that are associated to dropout in schools. More details, dropout of students due to conflict has been given table 3 .

Table 3 : Dropout of students due to conflict

\begin{tabular}{|l|l|c|c|}
\hline S.N. & Causes & Numbers & Percent \\
\hline 1 & $\begin{array}{l}\text { Interest of } \\
\text { opposite sex }\end{array}$ & 25 & 31.25 \\
\hline 2 & $\begin{array}{l}\text { Aggressive } \\
\text { behavior }\end{array}$ & 20 & 25 \\
\hline 3 & $\begin{array}{l}\text { Victim of } \\
\text { conflict }\end{array}$ & 15 & 18.75 \\
\hline 4 & $\begin{array}{l}\text { Other } \\
\text { accidents }\end{array}$ & 20 & 25 \\
\hline 5 & Grand total & 80 & 100 \\
\hline
\end{tabular}

Table 3 shows that interest of opposite sex is a main cause of dropout in school. It is obviously a terrible fact. On the other hand, findings indicate that 18.75 percent of the students have dropout the school being the victim of conflict, and moreover, 25 percent of the students have dropout school due to other accidents.
Additionally, sample class teacher said that the students more negative attitude toward their children used more physical punishment and who permitted higher levels of aggression in their children were more likely to have more aggressive. Other cause of dropout identify by the sampled students included that bulling is a cause of dropout. According to Sweeta the boy who bullies her act is superior because are older, a few friends who are classmate to support her try to help, deal with their kind of bullying. "When I was going to school with my classmate Sunita, walking from my house on the way. When hug gang who were wearing rough dresses met us in separate area, they disturbed us they did not only bother but also misbehaved and tried to poke Sunita. It's become very tease with them but all of them attacked us casually I never felt fear but I would felt it. So I did not go to school a week but Sunita left this school due to these bullied".

\section{Suggestive measures for conflicts management in school}

The last objective is carrying out this study was to suggest the measures for conflict management in school. The findings showed that, the causes of conflict in public school are varied. Resolution of various form of conflict would therefore, require specific strategies since the root causes may be differences. The samples head teacher was suggest that conflict management styles (competing, avoiding, collaborating, compromising and accommodations) are essential in order to utilize them for handling conflict in schools level.

The sampled teacher suggest that proper communication, encourage of students practice high level of maturity and training in conflict management is an essential in effective management of conflict at schools level. Further suggest the measures for conflict management identified by the sample students included: head teacher, class teacher, peer group and parents can play the vital role of conflict management. 
Table 4: Role of conflict management

\begin{tabular}{|l|l|c|c|}
\hline S.N. & Causes & Number & Percent \\
\hline $\mathbf{1}$ & Head teacher & $\mathbf{2 5}$ & 31.25 \\
\hline $\mathbf{2}$ & Class teacher & $\mathbf{2 0}$ & $\mathbf{2 5}$ \\
\hline 3 & Peer group & 15 & 18.75 \\
\hline 4 & Parents & 20 & 25 \\
\hline 5 & Grand total & 80 & 100 \\
\hline \multicolumn{4}{|c|}{ Source: field survey, 2013 }
\end{tabular}

The results shown in table 4 indicate that the involvement of head teacher in conflict management is dominant i.e. 31.25 percent on the other hand, there has been 18.75 percent of peer group involvement of conflict management. Similarly, class teacher involvement is 25 percent.

Further this finding indicates that 25 percent of conflict can be managed by neither by head teacher, students, nor class teacher. In this situation parents of both related students have to be called. In fact, of this conflicts responsible for increasing the violence which imparts negative impact in both the physical and mental status of students.

\section{Conclusion}

The study concludes that the majority of the students are included by any of the conflict. Reasons for such conflict were interest of opposite sex, aggressive behavior, teaching learning process and other activities: different in individual capabilities, different in their socio-economic backgrounds back at home and limited facilities etc. The students especially with lower socio-economic status along with the poor educational status study in public schools. Proper communication, encourage of students practice high level of maturity and training in conflict management is an essential in effective management of conflict at schools level. Therefore, school or head teacher can guide and counsel both the parents and students and it plays a vital role in conflict management.

\section{References}

Adeyemi, T.(2009). Principals 'management of conflicts in public secondary schools in Ondo State, Nigeria: A critical survey. Vol -9, 418-426.

Adomi, E. \& Anie, S. (2005).Conflict management Nigerian University. Journal of Library Management. Vol 2, 520-530

Derosier, E. \& Marcus, R.(2005). Building friendship and combating bullying: effectiveness, New York: MC Grow Hill.

Fisher,R.(1997). Interactive conflict resolution. New York: Syracuse University press.

Likert ,R.(1976). .New way of management of Conflict, New York,: MC Grow Hill.

Pollard, A. (1994).Teaching and learning in the primary school, London: Rutledge.

Thapa,T, (2010). Educational Management and organizational behavior (In Nepali), Kathmandu: Sunlight publication.

Thapa, T. (2008).Conflict management in school. Journal of EPMAN , Vol -1, 100-104

Uppadya, N. (2012). Head teacher: conflict management in School. Birgunj:Unpublished Master's degree dissertation TRMC, T.U.

Upreti, B.(2005).Conflict management. (In Nepali) Kathmandu: Bhrikuti Publication 